\title{
Chapter 15 \\ Manufactured in the Peri-Urban: \\ Regenerative Strategies for Critical \\ Lands
}

\author{
Giuseppe Guida $(\mathbb{D}$
}

\subsection{Productive Peri-Urban}

The adoption of a regenerative approach to the development of the contemporary city (Cole, 2012; Girardet, 2010; Newmann et al., 2017) leads to assign a determining role to the peri-urban territories. These "intermediate lands" are characterized by complex uses, often at the service of denser urban systems, but with which they are not compatible. A condition that generates operational landscapes (Brenner, 2016), wastescapes (Amenta \& van Timmeren, 2018; REPAiR, 2020), abandoned infrastructures, underused areas, rural fringes, etc. The term peri-urban, as understood in this chapter, therefore, identifies places that cannot be thematized only as the infiltration of urban functions in the rural environment, but that present spatial and functional peculiarities such as to define an original nature (Wandl et al., 2014). However, although peri-urban territories are characterized by some common characteristics, Europe, the United States and the large and fluid "peri-urban interfaces" of the large African and Asian agglomerations have substantially different spatial and functional forms (McGregor et al., 2006). In this chapter, although within a more general background, reference is made to the peri-urban territories typical of the European and, more specifically, Italian context. In such contexts, the peri-urban-apparently external to urban contexts and often considered as an unresolved "hybridization" area-presents, both from a spatial and functional point of view, similar characteristics to what is traditionally classified as an urban context (Brenner, 2014). More specifically, in these areas urban, natural and rural components interact (Forman, 2008) creating more complex forms than those of the traditional metropolitan model. In the latter, in fact, the peri-urban territories coincided with the margin areas, geographically peripheral compared to the extension of the settlement system, and hierarchically

\footnotetext{
G. Guida $(\bowtie)$

Department of Architecture and Industrial Design,

University of Campania "Luigi Vanvitelli", Aversa, Italy

e-mail: giuseppeguida@unicampania.it
} 
dependent on the center, characterized by high settlement densities and the presence of valuable functions. On the other hand, within the contemporary peri-urban territories, margins and boundaries appear rearticulated, the urban centers multiplied and deconstructed, settlement systems fragmented and permeated by shreds of countryside and nature (Formato \& Guida, 2018). Therefore, they are an integral part of what Soja defines as "post-metropolis" (2000), an agglomeration in which urbanization takes on a regional dimension and in which density is no longer an exclusive feature of the central cities (Balducci et al., 2017). Precisely because of the changing scale of contemporary urbanization processes, the metropolitan dimension appears today to be the most suitable to capture the forms and characteristics of peri-urban territories. In fact, it is at this scale that the complex assembly of "territorial issues" emerges clearly_linked to the multiple infrastructural and settlement needs, to the widespread informal and unregulated phenomena (Guida, 2015) and the equally widespread disposal processes_-which determines the hybrid and composite nature of the peri-urban territories. The widespread presence of "latent" risks also contributes to increasing the complexity of peri-urban territories (Guida, 2020) and that is, often devoid of immediate evidence but that significantly affects the quality and requires the triggering of regenerative processes: the combination of industrial activities, illegal waste deposits, landfills, sometimes even long-used, intensive agricultural activities, generates, in fact, multiple forms of pollution and/or alteration of environmental matrices (soil, water, air, etc.). However, the heterogeneous elements that structure these territories can be recombined (Shane, 2005), to generate new urban forms and, at the same time, increase the potential, available natural and social capital of metropolitan territories through regeneration processes of "waste." In this sense, the peri-urban territories can be understood as articulated places for the purposes of a wider regenerative strategy of the contemporary metropolis. On the one hand, waste processes specific to urban areas with higher density land in the peri-urban fringes, often generating crisis conditions, on the other hand, it is precisely these fringes that offer potential and space for the activation of regenerative processes to encourage regulation of the metabolic flows of the wider urban areas of which they are part (Galderisi \& Guida, 2020).

Thus, proposing for these territories "visions" strictly connected with the circular economy model. A model, as it is known, fundamentally different from the "linear economy," based on a simple, linear process; extract, produce, consume and trash, with little or no attention to the pollution generated at each step (EC, 2020; Sauvè et al., 2016).

This chapter aims to discuss a particular type of peri-urban, where the aforementioned issues interact with industrial clusters "landed" in many regions of southern Italy with the aim of encouraging the industrialization process and economic development, but also conflicting with the rural and urban identity of the territories, proposing for them "visions" strictly connected with the circular economy model.

P.U.R.E. (Productive and Urban metabolism Resources. Eco-solutions for new lands) research in this complex context, where the urban and economic planning tools alone have proved ineffective and unable to adequately read the mosaic of this 
"plural" territory. The research, first of all, both through cartographic and socioeconomic analyses of data (elaborated by a Geographic Information System-GIS), and then, also through educational laboratories, elaborating strategies of regeneration and spatial planning, and ecosystem reconfiguration of this urban-industrial-rural with a focus on the area of the province of Caserta in Campania Region. An important part of this area is also known with the ancient Roman name of Campania Felix, but today unfortunately known as Terra dei Fuochi (Land of Fires), due to air pollution following the continuous illegal burning of waste materials, in turn the result of partly illegal manufacturing activities. In this peri-urban magma, the research focuses on the role that industrial platforms, now enveloped in the urban fabric in constant growth up to a decade ago, can have in relation to the still existing cities and rural areas.

\subsection{Productive/Urban: Caserta Case Study}

The focus area of the research is the province of Caserta, and in particular the industrial/urban contexts, large areas where industrial settlements, cities and agricultural areas compete for the territory.

The large plain which consists of this patchwork has been affected by locations of large industrial settlements, plants, logistics, landfills and territorial large infrastructures that clash with residential, agricultural or residual areas and in-between natural ones and a mainly polluted hydrographic network (the Regi Lagni, the Volturno River, the Agnena canal, etc.).

Essentially, this mosaic of different urban and territorial facts (Russo, 2011) is the result of the industrial development planning activated by the Cassa per il Mezzogiorno (a public body that promoted and financed development policies for the South of Italy until the 1980s) and regulated by Law n. 634 of 1957 and subsequent decrees and circulars. Legislation provided for the possibility of forming consortiums between Municipalities, Provinces, Chambers of Commerce, banks, and so on, with the aim of promoting industrial initiatives to be concentrated in specific areas, called Industrial Development Areas (ASI) (in Italian, Aree di Sviluppo Industriale-ASI). The implementation of these policies was preceded by a so-called phase of "preindustrialization," in which the action of the Cassa was dictated by the cogency of the agrarian issue and unfolded through a first transformation and infrastructuring of the South (Adorno, 2015). The interventions were implemented following the approval of specific plans, drawn up by the consortiums, which have the value of Territorial Coordination Plans (provided for by the Italian Law n. 1150/42), with respect to which the municipalities are required to standardize their urban planning tools. The plans of the ASI areas were extended to the entire territory of the municipalities included in the consortium and, in addition to providing for the works to be carried out by the consortiums, could include indications on the needs of general infrastructure, public works and services. In summary, it was a sui generis urban planning that, between the 1960-1970s, surrogate the regional and provincial and filled a void of municipal planning determining, as in the case of the territory of 
Caserta, a particular type of peri-urban, with clear agricultural, urban, and industrial components. The coordination between the plans of the ASI and the municipal plans almost never happened, creating "fractures" in the territories, contributing to separate the industrial plates from the urban and rural contexts, creating industrial enclaves, also from an administrative point of view. A condition that has gradually worsened with the crisis and the closure of many activities since the 1990s.

The ASI are made up of "industrial agglomerations," where factories are concentrated. The localization of the agglomerations took place in such a way as to allow industrial investors to find, in addition to the proximity to the main mobility infrastructures and urban centers, a network of small industrial settlements already active, so as to take advantage of the supply chain system and the interrelations between the different stages of the production process.

In general, the implementation timing of agglomerations did not always coincide with the changes in Fordist and post-Fordist industrial economic processes. For this reason, the actual realization of the ambitious program of the heavy industrialization of the South was delayed, when the metamorphoses of the productive system, the delocalizations in areas with low-cost labor and disposal processes had already been activated. Over the decades, this partial failure was associated with spontaneous or planned urban transformations (both residential and other productive ones, for example, the areas of the Productive Settlement Plans-PIP acronym in Italian) induced precisely thanks to the infrastructure built by and for the ASI, which have contributed to the territorial disorder and urban quality in terms of services and equipment.

\subsection{The Path of P.U.R.E. Research}

The aims of P.U.R.E. research are to provide a methodology for the analysis, classification and mapping of abandoned or underutilized areas; to define a catalogue of ecosolutions for their regeneration and guidelines to improve the integration of industrial clusters in the urban territories. In this sense, the eco-innovation of design solutions for "new lands" is crucial. Eco-innovation, as defined by the European Commission (EC), is a form of innovation designed to promote development opportunities and environmental safeguard, optimizing the use of resources. The EC has also defined an Eco-Innovation Action Plan (EcoAP) (EC, 2011). The above concepts will have as the field of investigation the Industrial Development Area (ASI) in the District of Caserta (Fig. 15.1). The attempt to integrate these areas with the urban, rural, and natural surrounding areas has never been made and today these areas are only partially active and have left thousands of hectares of brownfield areas. The research will work on the quality of single areas but also on their relationship with neighbor urban and/or rural contexts, transforming each area into a spatial/functional element of an articulated network of open spaces for technological, ecological-environmental, and social needs. The analysis, classification and mapping of disused areas, internal and close to ASI, in addition to returning an unpublished soil map, will bring out 


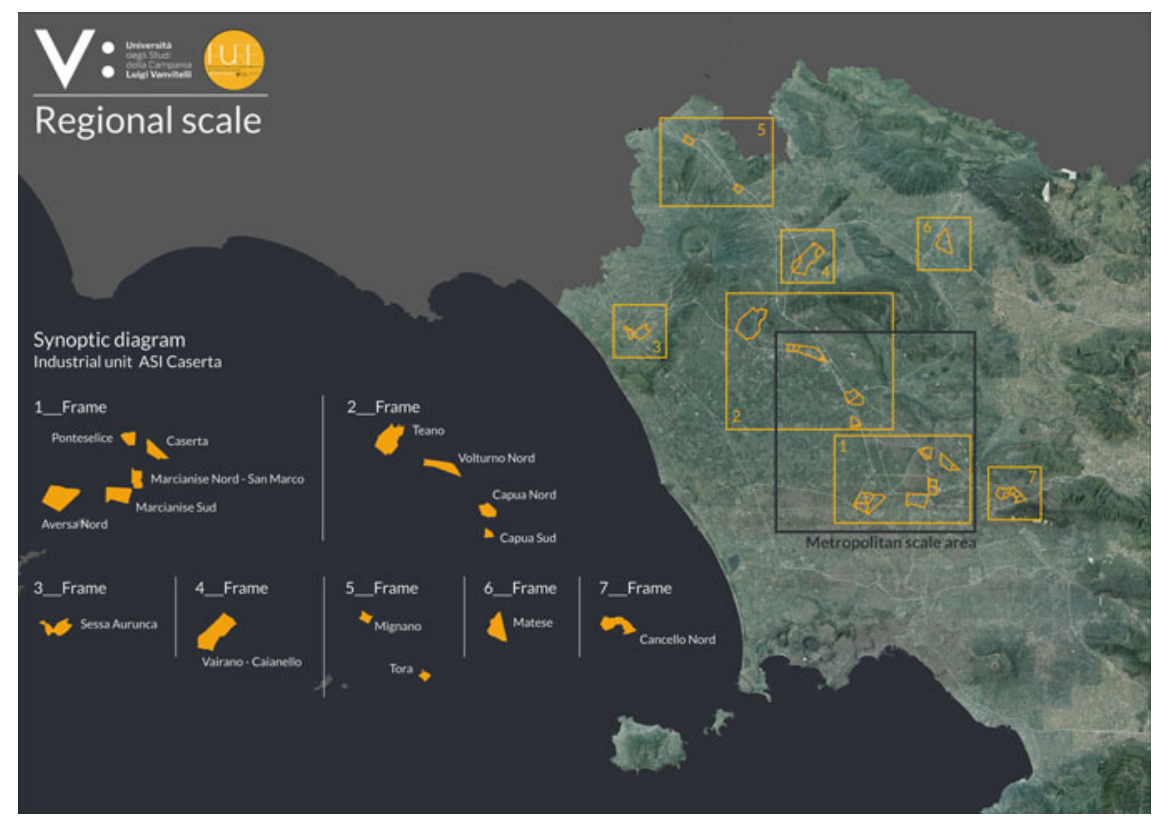

Fig. 15.1 The agglomerations of Industrial Development Area of Caserta (Italy) (Source PURE Laboratory of Department of Architecture and Industrial Design of University of CampaniaGiovanni Bello)

some paradigmatic areas where design exemplifications will allow to test possible eco-innovative solutions. The methodology of P.U.R.E. project is structured into three phases. The first includes both the preliminary collection of data and maps from the ASI, Caserta District, Campania Region, Cassa del Mezzogiorno and the selection of a set of criteria for analyzing, classifying, and mapping brownfields or underused areas. The second phase involves the editing of a catalogue of already tested eco-solutions at an international level, with a focus on soil restoration, reuse of waste materials (in particular CDWs), ecological techniques suitable for brownfields areas. These activities will end with the elaboration of thematic GIS maps. These two phases are underway and have been implemented through the Urban Planning Educational Laboratory, both in the analytical phase and in the proposal of strategies and visions, at an intermediate scale, called "Focus scale." The third phase is aimed at applying the outcomes of the previous ones to the pilot area of the ASI, at "Sample scale." The outlined criteria will allow to carry out, within the pilot area, analytical maps of the brownfield areas and the identification of the residual natural, semi-natural, agricultural or green areas. To date, the data is being entered into a GIS platform intended as an innovative knowledge framework, nowadays not available, able to support regeneration actions. The use of open-source maps will integrate the database with information about the quality of the soils, the physical condition of the buildings and infrastructures and the function they contain. In particular, the use 


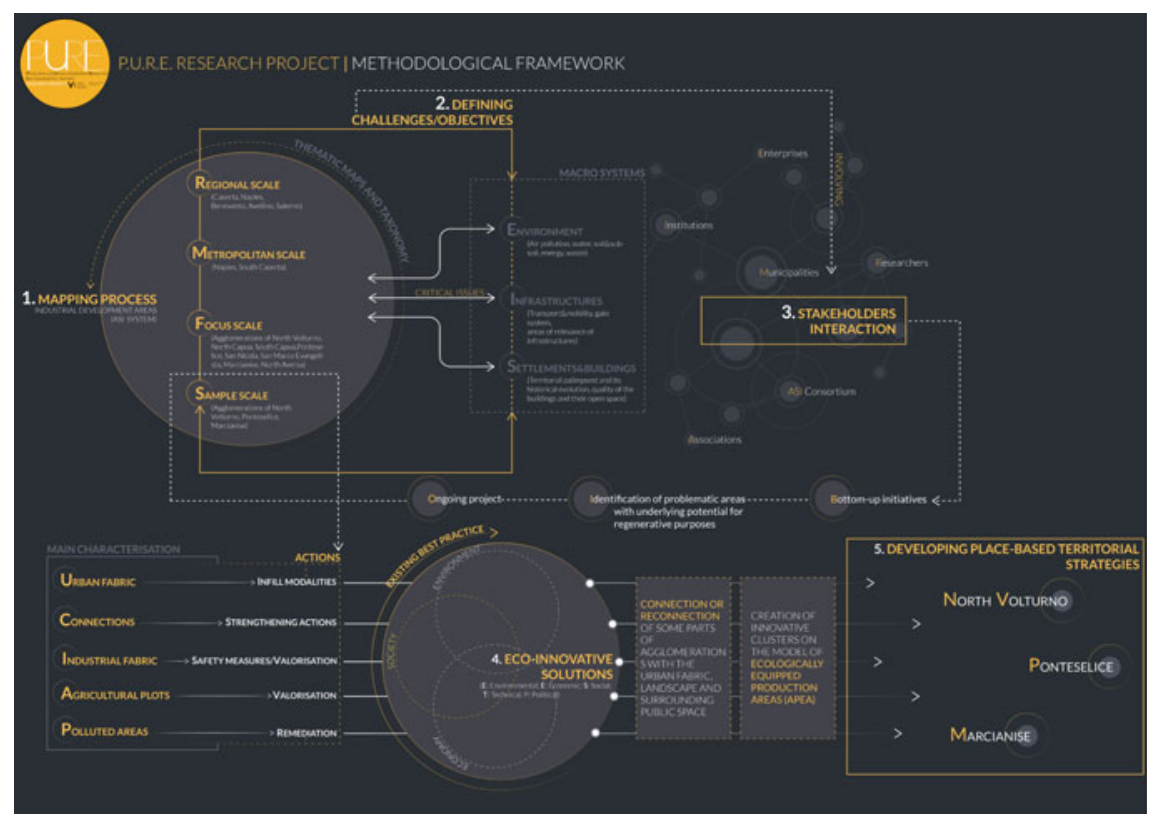

Fig. 15.2 The PURE research methodological framework (Source PURE Laboratory of Department of Architecture and Industrial Design of University of Campania-Valentina Vittiglio)

of multitemporal satellite images will allow for the analysis of the electromagnetic response of the territory in order to acquire information that is not visible. Then, some targeted design tests will be carried out, in order to define alternative place-based strategies on three selected sample areas. The outlined path is in Fig. 15.2.

\subsection{First Steps, Expected Results and Future Research Paths}

The P.U.R.E. research project, which will end in 2021, aims for some specific and complementary results. The first outcome is an implementable GIS mapping model, replicable at different scales, able to represent the state of the soil, its uses, the dimensions of abandonment and degradation of the 14 agglomerations (covering about 4000 hectares) and the urban and rural areas adjacent to them. The second result is specifically connected to the territorial and industrial nature of this research call. Soil reuse practices are conceived both in a dimension of the urban and territorial project (able to coordinate the needs of the production with the priorities of the cities), and specific intervention techniques. Starting from a circular and regenerative approach, the results of the project suggest replicable methods and models aimed at 
reducing waste and soil consumption, while also promoting recovery and regeneration. In the three focus project areas, the possible reuse of waste materials, such as CDWs, will also be tested. All this in order to be able to configure these territories as ecosystems, assessing the interrelationships between the anthropic and natural phenomena. Considerable importance will be given to the evolution of the research methodology, proposing it for the entire South, reconstructing cartographically the history of the industrialization of the South of Italy and returning the current state of affairs, with elaborations in GIS, statistical data, economic indicators, spatial and functional relationship with the neighboring urban organisms. The final outcome may be an interpretative model to be proposed as a fundamental support to decisions and to the definition of specific national intervention policies.

\section{References}

Adorno, S. (2015). Le Aree di sviluppo industriale negli spazi regionali del Mezzogiorno. Available at http://www.treccani.it/enciclopedia/le-aree-di-sviluppo-industriale-negli-spazi-regionalidel-mezzogiorno_\%28L\%27Italia-e-le-sue-Regioni\%29/.

Amenta, L., \& van Timmeren, A. (2018). Beyond wastescapes: Towards circular landscapes. Addressing the spatial dimension of circularity through the regeneration of wastescapes. Sustainability, 10(12), 4740. https://doi.org/10.3390/su10124740.

Balducci, A., Fedeli, V., \& Curci, F. (Eds.). (2017). Metabolismo e regionalizzazione dell'urbano. Guerini e Associati.

Brenner, N. (Ed.). (2014). Implosions/explosions: Towards a study of planetary urbanization. Berlino: Jovis.

Brenner, N. (Ed.). (2016). Stato, spazio, urbanizzazione. Guerini.

Cole, R. J. (2012). Transitioning from green to regenerative design. Building Research and Information, 40(1), 39-53. https://doi.org/10.1080/09613218.2011.610608.

EC-European Commission. (2011). Eco Innovation Action Plan. https://eurlex.europa.eu/LexUri Serv/LexUriServ.do?uri=COM:2011:0899:FIN:EN:PDF.

EC-European Commission. (2020). EU Circular Economy Action Plan. https://ec.europa.eu/env ironment/circular-economy/.

Forman, R. T. (2008). Urban regions: Ecology and planning beyond the city. Cambridge University Press.

Formato, E., \& Guida, G. (2018). Ripartire dai wastescapes lungo le infrastrutture della mobilità. Per un progetto di rigenerazione della Terra dei fuochi. In Proceedings SUM2018, Fourth Symposium on Urban Mining and Circular Economy. CISA Publisher.

Galderisi, A., \& Guida, G. (2020). Territori periurbani oltre la sostenibilità: luoghi snodo per l'attivazione di strategie rigenerative, in Archivio di Studi Urbani e Regionali (ASUR) $\mathrm{n}$. 127/2020. https://doi.org/10.3280/ASUR2020-127004.

Girardet, H. (2010). Regenerative cities, world future council and HafenCity University. Available at: https://www.worldfuturecouncil.org/wp-content/uploads/2016/01/WFC_2010_Regener ative_Cities.pdf. Last access 18 Jan 2021.

Guida, G. (2020). Rischio liquido. Pianificare il periurbano tra paesaggi dello scarto e flussi di rifiuti. In A. Galderisi, M. di Venosa, G. Fera, \& S. Menoni (Eds.), Geografie del rischio. Nuovi paradigmi per il governo del territorio. Donzelli Editore.

Guida, G. (2015). Città metropolitane a Mezzogiorno, in id. (ed.), Città Meridiane. La questione metropolitana al Sud. La Scuola di Pitagora Editrice. 
McGregor, D., Simon, D., \& Thompson, D. (2006). The Peri-Urban interface: Approaches to sustainable natural and human resource use. Earthscan.

Newmann, P., Beatley, T., \& Boyer, H. (2017). Resilient cities: Overcoming fossil fuel dependence (2nd ed.). Island Press/Center for Resource Economics.

Repair (2020). Horizon 2020 Project. Available at: http://h2020repair.eu/project-results/project-rep orts/. Last access 18 Jan 2021.

Russo, M. (2011). Città Mosaico. Il progetto contemporaneo oltre la settorialità. Clean.

Shane, G. D. (2005). Recombinant urbanism. Conceptual Modeling in architecture, urban design, and city theory. Wiley.

Sauvé, S., Bernard, S., \& Sloan, P. (2016, January). Environmental sciences, sustainable development and circular economy: Alternative concepts for trans-disciplinary research. Environmental Development, 17, 48-56. https://doi.org/10.1016/j.envdev.2015.09.002.

Soja, E. (2000). Postmetropolis: Critical studies of cities and regions. Basil Blackwell.

Wandl, A., Nadin, V., Zonneveld, W. A. M., \& Rooij, R. M. (2014, October). Beyond urban-rural classifications: Characterising and mapping territories-in-between across Europe. Landscape and Urban Planning, 130, 50-63. https://doi.org/10.1016/j.landurbplan.2014.06.010.

Open Access This chapter is licensed under the terms of the Creative Commons Attribution 4.0 International License (http://creativecommons.org/licenses/by/4.0/), which permits use, sharing, adaptation, distribution and reproduction in any medium or format, as long as you give appropriate credit to the original author(s) and the source, provide a link to the Creative Commons license and indicate if changes were made.

The images or other third party material in this chapter are included in the chapter's Creative Commons license, unless indicated otherwise in a credit line to the material. If material is not included in the chapter's Creative Commons license and your intended use is not permitted by statutory regulation or exceeds the permitted use, you will need to obtain permission directly from the copyright holder.

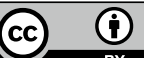

